\title{
POSITIVE CORRELATION BETWEEN DISEASE ACTIVITY INDEX AND MATRIX METALLOPROTEINASES ACTIVITY IN A RAT MODEL OF COLITIS
}

\author{
Luiz Gustavo de OLIVEIRA ${ }^{1}$, André Luiz da CUNHA ${ }^{1}$, Amaury Caiafa DUARTE ${ }^{1}$, \\ Maria Christina Marques Nogueira CASTAÑON ${ }^{2}$, Júlio Maria Fonseca CHEBLI ${ }^{3}$ and \\ Jair Adriano Kopke de AGUIAR ${ }^{1}$
}

\begin{abstract}
Context - Inflammatory bowel disease, including ulcerative colitis and Crohn's disease, comprising a broad spectrum of diseases those have in common chronic inflammation of the gastrointestinal tract, histological alterations and an increased activity levels of certain enzymes, such as, metalloproteinases. Objective - Evaluate a possible correlation of disease activity index with the severity of colonic mucosal damage and increased activity of metalloproteinases in a model of ulcerative colitis induced by dextran sulfate sodium. Methods - Colitis was induced by oral administration of 5\% dextran sulfate sodium for seven days in this group $(n=10)$, whereas control group $(n=16)$ received water. Effects were analyzed daily by disease activity index. In the seventh day, animals were euthanized and hematological measurements, histological changes (hematoxylin and eosin and Alcian Blue staining), myeloperoxidase and metalloproteinase activities (MMP-2 and MMP-9) were determined. Results - Dextran sulfate sodium group showed elevated disease activity index and reduced hematological parameters. Induction of colitis caused tissue injury with loss of mucin and increased myeloperoxidase $(P<0.001)$ and MMP-9 activities ( 45 fold $)$ compared to the control group. Conclusion - In this study, we observed a disease activity index correlation with the degree of histopathological changes after induction of colitis, and this result may be related mainly to the increased activity of MMP-9 and mieloperoxidase.
\end{abstract}

HEADINGS - Colitis. Crohn disease. Metalloproteinases.

\section{INTRODUCTION}

Inflammatory bowel diseases (IBD) have in common chronic inflammation of the digestive tract, which may or may not have a cause or specific patho$\operatorname{gen}^{(5,7)}$. Its etiology is multifactorial and complex, it is believed to have genetic involvement, environmental, immune and intestinal microbiota ${ }^{(26,30)}$.

For many years, studies on the understanding of the pathogenesis of IBD have been delayed by the lack of experimental models that corresponded to the disease $^{(10)}$. But now more than 30 models have been developed, with the most varied clinical manifestations of IBD ${ }^{(4,18)}$. These models contribute to important advances in understanding the mechanisms of inflammation, the pathogenesis and the treatment of possible discoveries ${ }^{(11)}$. Among the models used, stands the induction of colitis by dextran sulfate sodium (DSS), due to its good reproducibility and also for presenting clinical symptoms, inflammatory markers and histopathological features similar to IBD in humans ${ }^{(17,21)}$. The exact mechanism by which the DSS induced colitis is unknown but it is known that this compound is toxic to intestinal epithelial cells with a probable mechanism that has direct action on intestinal permeability allowing entry of luminal antigens resulting in an inflammatory response ${ }^{(22,29)}$.

Changes in the activity and expression of extracellular matrix metalloproteinases (MMPs) were described in IBD patients suggesting that these enzymes are involved in tissue degradation process ${ }^{(16,20)}$. MMPs are endopeptidases dependent of calcium and zinc and are considered the main enzymes involved in the control of the homeostasis of extracellular matrix $(\mathrm{ECM})$ at various levels, including growth, division and cell function, regulation of immune response, controlled synthesis and matrix remodeling by cleavage of almost all of its components such as collagen, proteoglycans, fibronectin, elastin, and laminin ${ }^{(15,24)}$.

Declared conflict of interest of all authors: none.

Research performed at: Laboratório de Análise de Glicoconjugados do Departamento de Bioquímica, Instituto de Ciências Biológicas, UFJF, Juiz de Fora, MG, Brasil. ${ }^{1}$ Laboratório de Análise de Glicoconjugados, Departamento de Bioquímica, Instituto de Ciências Biológicas, Universidade Federal de Juiz de Fora - UFJF; ${ }^{2}$ Departamento de Morfologia, Instituto de Ciências Biológicas, UFJF. ${ }^{3}$ Disciplina de Gastroenterologia, Faculdade Medicina, UFJF, Juiz de Fora, MG, Brasil.

Correspondence: Dr. Jair Adriano Kopke de Aguiar. Universidade Federal de Juiz de Fora. Departamento de Bioquímica/ICB - Rua José Lourenço Kelmer, s/n - Campus Universitário - Bairro São Pedro - 36036-900 - Juiz de Fora, MG, Brasil. E-mail: jair.aguiar@ufjf.edu.br 
Several MMPs (MMP-1, MMP-2, MMP-3, MMP-8, MMP-9, MMP-12) have their activity increased in a variety of animal models colitis and in patients with inflammatory bowel disease. Thus, the present study investigated a possible correlation of DAI in the model of ulcerative colitis induced by DSS with the severity of colonic mucosal damage and increased activity of MMP-2 and MMP-9.

\section{METHODS}

\section{Materials}

Dextran sodium sulfate (DSS - MW: 36-50 kDa, MP Biomedicals, Solon, OH, USA), hexadecyltrimethylammonium bromide (HTAB, Sigma-Aldrich Co., St. Louis, MO, USA), $o$-dianisidine hydrochloride (Sigma-Aldrich Co., St. Louis, MO, USA); Acrylamide (Ludwig Biotechnology Ltd., Porto Alegre, RS, Brazil); $N, N$ '-methylenebisacrylamide (Neon Comercial Ltda., São Paulo, SP, Brazil); Tris(hydroxymethyl)aminomethane (Biosolve Valkenswaard, Netherlands); Triton x-100 (Vetec Fine Chemicals Ltda., Duque de Caxias, RJ, Brazil); Gelatin (Sigma-Aldrich Co., St. Louis, MO, USA).

\section{Animals}

Male Wistar rats (6-8 weeks old) were obtained from the Center of Biology for Reproduction (CBR) at Federal University of Juiz de Fora (UFJF, Juiz de Fora, MG, Brazil) for induction of colitis by DSS. The animals were kept in a bioterium of Laboratório de Análise de Glicoconjugados in the Biochemistry Department (UFJF), throughout the experiment in individual plastic boxes under, "Guide for the Care and Use of Laboratory Animals". The procedures were approved by the Ethics Committee on Animal Experimentation UFJF (002/2010-CEEA UFJF).

\section{DSS induced colitis}

The induction of colitis DSS was done according Okayasu et al. with modifications. The animals were randomized into two groups: control group $(\mathrm{n}=16)$, which was given water and the DSS group $(n=10)$ given only a solution of $5 \%$ DSS ad libitum for 7 days. The total volume of DSS consumed per rat was about $40 \mathrm{ml} /$ day per group. At the end of the experiment (seventh day), rats were euthanized by deepening anesthesia with administration of sodium pentobarbital $(100 \mathrm{mg} / \mathrm{kg})$ and the colon was completely removed from the colon-cecal junction to the anal canal.

\section{Assessment of disease activity index}

All the rats were observed once a day. The disease activity index (DAI) was determined by scoring body weight loss, trait of stool, and occult blood in stool or hematochezia from day 0 to day 7 in colitis induction according to the classic scoring system by Cooper in the process of modeling: body weight loss $(0$, none; $1,1 \%-5 \% ; 2,5 \%-10 \% ; 3,10 \%-20 \% ; 4,>20 \%)$, stool consistency ( 0 , normal; 2 , loose stool; 4 , diarrhea), and stool blood ( 0 , negative; 2 , fecal occult blood test positive; 4 , gross bleeding) $)^{(6)}$

\section{Hematological Evaluation}

Blood samples were analyzed for the number of erythrocyte, hematocrit and hemoglobin for the evaluation of hematological parameters. The analysis was performed at the Center for Reproductive Biology (CBR/UFJF) using the veterinary hematology analyzer Poch 100i V-Diff (Sysmex).

\section{Histopathologic analysis}

Initially, each colon segment was washed in $0.1 \mathrm{M}$ phosphate buffer, $\mathrm{pH} 7.4$, and its length and weight measured to evaluate the ratio length/weight. After the colon was opened longitudinally, using the technique of swiss roll, fixed with paraformaldehyde solution $10 \%$ in $0.05 \mathrm{M}$ phosphate buffer, $\mathrm{pH} 7.4$, for at least 24 hours, embedded in paraffin and processed so that cuts of $5 \mathrm{~mm}$ thick were performed. Besides the normal staining (hematoxylin and eosin, HE) it was also used a specific one mucopolysaccharides alcian blue at $\mathrm{pH}$ 2.5. The sections were graded histopathologically and evaluated as described by Cooper et al. ${ }^{(6)}$.

\section{Myeloperoxidase activity (MPO)}

The tissue MPO activity was measured according to the technique described by Bradley et al. ${ }^{(2)}$. The absorbance was determined at a wavelength of $450 \mathrm{~nm}$. The MPO activity was calculated using the molar extinction coefficient $\left(\mathrm{e}=11.48 \mathrm{mM}^{-1} \cdot \mathrm{cm}^{-1}\right)^{(8)}$. 1UE (enzyme unit) of myeloperoxidase was considered as amount of enzyme that degrades $1 \mu \mathrm{mol} / \mathrm{min}$ of hydrogen peroxide at $25^{\circ} \mathrm{C}$. The results were expressed in $\mathrm{mUE} / \mathrm{mg}$ protein.

\section{Extraction of metalloproteinases}

Fragments of the colon were macerated in liquid nitrogen and then added $1 \mathrm{ml}$ of Tris- $\mathrm{HCl} 50 \mathrm{mM} \mathrm{pH} \mathrm{7.4,} \mathrm{contain-}$ ing $100 \mathrm{mM} \mathrm{CaCl}_{2}$ and $1 \mathrm{ml}$ of Triton X-100 0.2\% (v/v) for extraction the enzymes. The samples were centrifuged for 10 minutes at $12,000 \mathrm{xg}$, and the supernatant aliquoted. Protein was quantified by BCA kit (Thermo Scientific).

\section{Zymograms}

Colon homogenates (10 $\mu \mathrm{g}$ protein) were submitted to a electrophoresis on polyacrylamide gels $(10 \%$ acrylamidebisacrylamide solution T $30 \%$ C $2.7 \%$ gelatin containing $2 \mathrm{mg} / \mathrm{ml})$ in Tris-glycine $(25 \mathrm{mM} / 192 \mathrm{mM}) \mathrm{pH} 8.3$ containing sodium dodecyl sulphate $(0.1 \%)$. After the migration, gels were washed with Triton X-100 (2\%) and incubated with 50 $\mathrm{mM}$ Tris- $\mathrm{HCl}, \mathrm{pH} 8.2$, containing $5 \mathrm{mM} \mathrm{CaCl}_{2}, 1 \mu \mathrm{M} \mathrm{ZnCl}_{2}$ and for $24 \mathrm{~h}$ at $37^{\circ} \mathrm{C}$. The gels were stained by Coomassie Brilliant Blue R-250 (0.5\% dye, 30\% methanol, $10 \%$ acetic acid) and destained (30\% methanol, $10 \%$ acetic acid) ${ }^{(19,27)}$. The activity of gelatinases was evidenced as bright regions (bleached) in the gel. To measure the intensities of the bands a program was used, TotalLab Quant ${ }^{\circledR}$. The activities were corrected for protein content.

\section{Statistical analysis}

Values are expressed as mean \pm standard error. Statistical analysis was performed using SPSS for Windows, version 19. 
We evaluated the data normality by the Shapiro-Wilk test, the comparison of data distributed on the curve of normality was performed by t test student. $P<0.05$ was considered statistically significant.

\section{RESULTS}

The clinical signs of DSS-induced colitis in rats were determined by assessing the disease activity index (DAI). This index is composed of three parameters (stool consistency, presence of rectal bleeding and weight variation of the animals) and provides the degree of severity of the inflammatory process that can be correlated with damage to the intestinal mucosa. We observed an increase in the DAI for the DSS group after the first day of induction with a significant increase from the fourth to the seventh day, in addition, significant weight loss during all days of the experiment (Figure 1. A, B), for the control group there was a gain of weight and no clinical changes. Weight loss was the first symptoms observed from the third day on showed changes in stool consistency, while the presence of blood was viewed from the fifth day (Figure $1 \mathrm{C}$ ). Macroscopically, there was also a reduction in the length of the colon group DSS (Figure 1 D).

The DSS-induced colitis caused hematological decreasing of erythrocyte count $(P<0.01)$, hematocrit $(P<0.05)$ and hemoglobin $(P<0.01)$, indicating severe loss of blood compared to the control group (Table 1).

TABLE1. Hemathological parameters analysis with blood (EDTA) in the animals of both control and DSS group

\begin{tabular}{lccc}
\hline Groups & $\begin{array}{c}\text { Erythrocyte } \\
\left(\mathrm{x} \mathrm{10} / \mathrm{mm}^{3}\right)\end{array}$ & $\begin{array}{c}\text { Hematocrit } \\
(\%)\end{array}$ & $\begin{array}{c}\text { Hemoglobin } \\
(\mathrm{g} / \mathrm{dL})\end{array}$ \\
\hline Control & $8.88 \pm 0.17$ & $48.0 \pm 1.0$ & $17.7 \pm 0.4$ \\
DSS & ${ }^{\mathrm{a}} 6.75 \pm 0.58$ & $\mathrm{~b} 39.3 \pm 2.6$ & ${ }^{\mathrm{a}} 13.1 \pm 1.0$ \\
\hline
\end{tabular}

Data represents the values of the mean \pm standard error

Significant statistical diferences are shown with ${ }^{a} P<0,01$ and ${ }^{b} P<0,05$ compared to the control
(A)
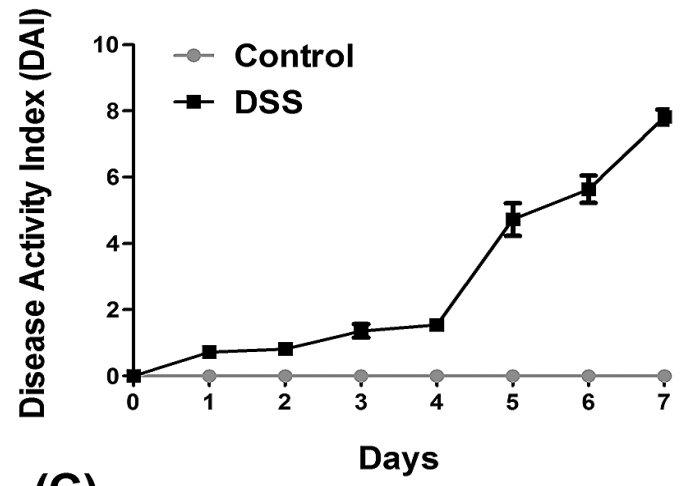

(C)

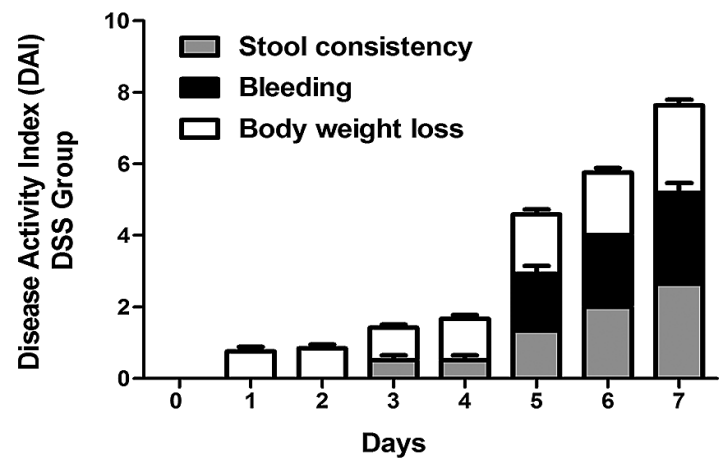

(B)

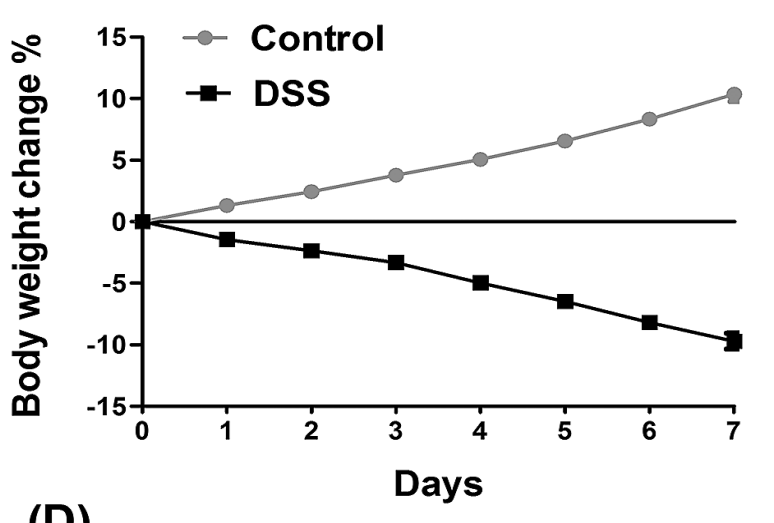

(D)

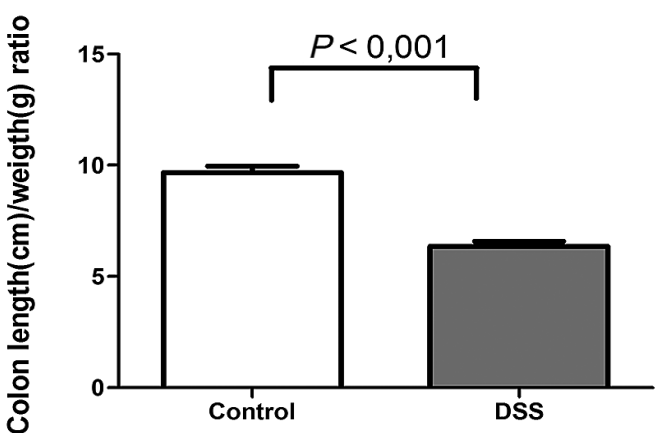

FIGURE 1. Assessment of disease activity index (DAI) in dextran sulfate sodium DSS-induced colitis model.

(A) The DAI of the DSS group presented a difference from the first day of the experiment and (B) a reduction in weight loss when compared to the control group. (C) DSS group began to demonstrate alterations in the consistence of their stool from the third day, and bleeding was noticed after the fifth day of the experiment while no alterations were observed on the control group. (D) The use of DSS caused shortening of the colon of the animals when compared to the control group. The data is demonstrated by the mean \pm standard error. DSS- dextran sulfate sodium 
Histological analysis of colonic mucosa of animals in the DSS group showed multifocal areas of erosion and ulcers as well as regions of loss of more than $2 / 3$ of the crypts. It was also observed vascular congestion, edema in the lamina propria and inflammatory infiltrate (Figure 2. A). Animals in the control group the colonic mucosa remained normal, with the epithelium and crypts intact (Figure 2. A). This result also observed in the analysis reflects the histological score (Figure 2. B, $P<0.001$ ). For alcian blue staining, we found out that the DSS group (Figure 2. A), had significant decreases in the number of goblet cells and mucin production while in the control group these numbers of crypts and goblet cells were maintained.
The activity of myeloperoxidase (MPO), a marker widely used to assess the tissue infiltration of neutrophils showed an increase in MPO activity compared to the control group (Figure 2. C). This result is consistent with the histopathological changes observed.

There is good evidence of the involvement of matrix metalloproteinases in inflammatory bowel disease, among them are two gelatinases (MMP-2 and 9). To evaluate changes in the activity of MMP-2 and MMP-9 in both controlled and induced group, densitometric analysis of zymograms was performed as described in materials and methods. It was observed in healthy animals only the activity of MMP-2 (Figure 3. A) while for the induced animals, besides the in-

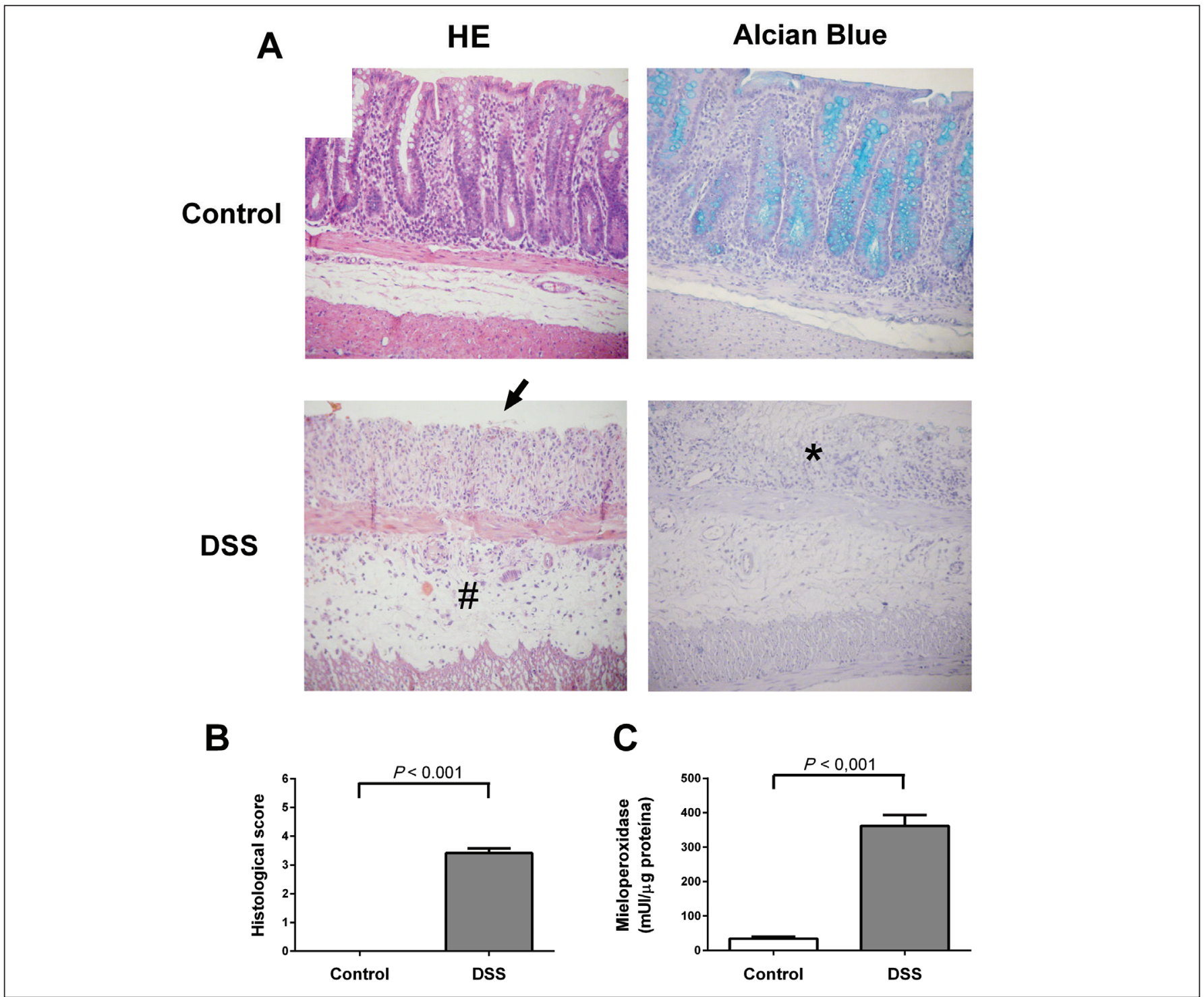

FIGURE 2. Histophatological changes and enzymatic activity present in the colon of the dextran sulfate sodium DSS-induced colitis model.

(A) Control group maintained normal colon, whereas DSS group shows the multifocal areas of the mucosal erosions with loss of epithelial cells (black arrow), goblet cell depletion (*), crypt loss, inflammatory cell infiltration, edema and vascular congestion. (B) The histophatologic score demonstrated a significant increase in the DSS group compared to the control, $(\mathrm{C})$ the same result was observed for the Myeloperoxidase activity (MPO) tissue activity. The colon was fixed and stained with $\mathrm{HE}$ and alcian blue $\mathrm{pH} 2,5$, original magnification 10x). 


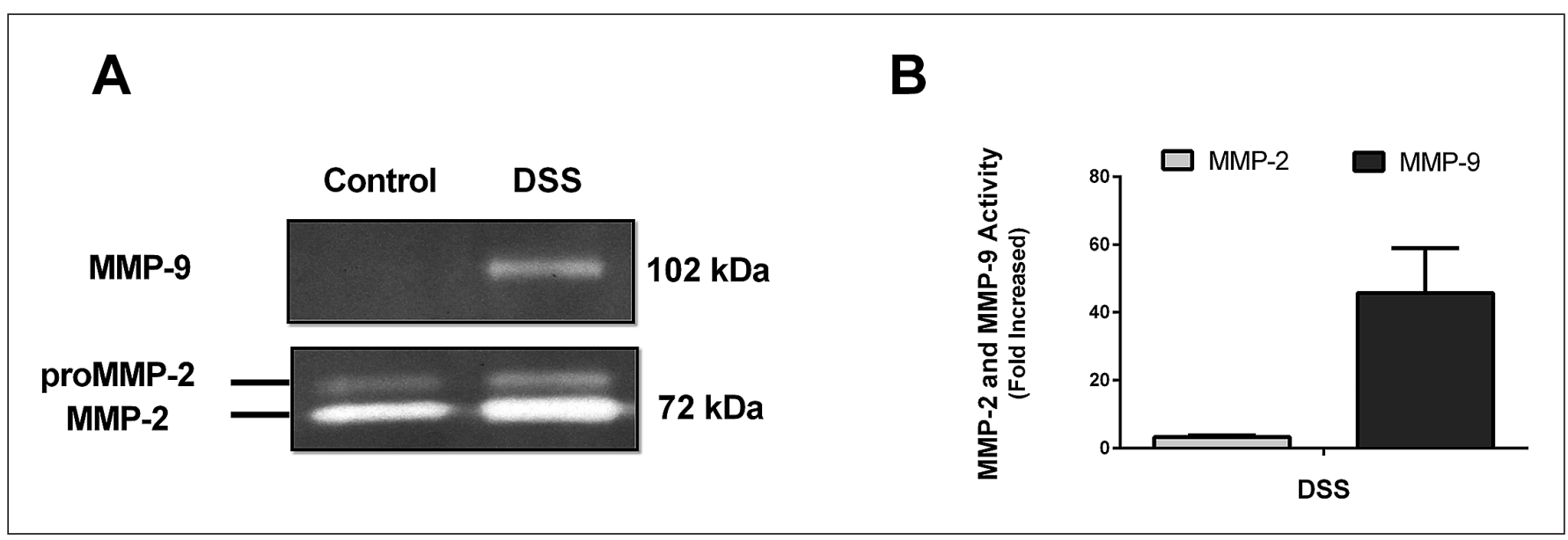

FIGURE 3. A representative zymogram of matrix metalloproteinases in the colon of the DSS-induced colitis model.

Aliquots $(10 \mu \mathrm{g}$ of protein) were submitted to electrophoresis in poliacrilamida gel at $10 \%$, containing gelatine $2 \mathrm{mg} / \mathrm{mL}$, as substrate. The activities of the metalloproteinase activities MMP-2 and MMP-9 were quantified by densitometry of the bands in gel slabs (A) and compared to the control (B). The data represents the mean \pm standard error.

creased activity of MMP-2 compared to the control group (3 fold), we noticed the onset of the activity of MMP- 9 (Figure 3. A, B).

\section{DISCUSSION}

The experimental model using DSS has as main clinical manifestations: diarrhea, bloody stools, weight loss, bleeding, and anemia ${ }^{(29)}$. The histological changes in the colon most commonly found are the decrease mucin, epithelial degeneration, presence of erosions, infiltration of neutrophils and crypt abscesses ${ }^{(22)}$. These manifestations and histopathological changes were also observed in our study, in addition to shortening of the length of the colon evaluated macroscopically. The diarrhea observed in the animals of group DSS from the third day may be due to increased permeability of the intestinal cells or by hyperosmolarity in the lumen caused by $\operatorname{DSS}^{(31)}$. The weight loss observed and shortening of the colon shows high correlation with the histological and pathological changes of colitis and are good markers of the severity of bowel inflammation ${ }^{(29,31)}$. Allied to these factors, the worsening of the disease occurs in the presence of acute bleeding evaluated by DAI and hematological measurements ${ }^{(12,29)}$. We observed a significant reduction in erythrocyte count, hematocrit and hemoglobin in the group DSS, indicating that these animals suffer large losses of blood.

The histopathological features observed in this animal model are very similar to the disease in humans ${ }^{(22)}$. In DSS colitis it was observed the presence of edema and inflammatory infiltrate in the lamina propria, loss of crypts and goblet cells (loss of mucins observed by alcian blue) along with multifocal areas of erosions and ulcerations demonstrating great tissue damage in the colon. The inflammatory infiltrate was observed and histologically confirmed by myeloperoxidase activity (MPO), a marker of inflammatory infiltrate often used in the model of colitis by DSS. MPO is a major enzyme found in the granules of neutrophils, it primarily catalyzes the oxidation of $\mathrm{Cl}^{-}$to hypochlorous acid and its increase is involved in tissue damage ${ }^{(23)}$. In our study, we observed a high activity of MPO in the DSS group compared to the control group $(P<0.001)$. Recent studies also showed that reduction in the degradation of matrix present in the intestinal mucosa can be related to a reduction in MPO activity and improves the course of the disease in an experimental model of colitis ${ }^{(13,14)}$.

Activity of extracellular matrix metalloproteinases is currently discussed in terms of its involvement with inflammatory bowel diseases. These enzymes and their inhibitors are produced by cells in the gastrointestinal tract, and a change in this balance can cause some inflammatory conditions in the intestine ${ }^{(15)}$. Within this group of enzymes stands, MMP-2 and MMP-9, known as gelatinases. MMP-2 is constitutively expressive while MMP-9 is absent in major human tissues ${ }^{(9)}$. Some lines of research suggests that these enzymes are involved in the process of destruction and tissue remodeling in inflammatory conditions ${ }^{(3,28)}$.

Our study shows a high activity of MMP-9 (45 fold increase) in the group DSS, while there was a slight increase in MMP-2 (three fold increase). Studies in patients with ulcerative colitis showed greater activity of MMP-9 compared to the control patients ${ }^{(1)}$. Studies on experimental models have already shown that animals deficient on MMP-9 attenuated colitis demonstrating that gelatinase is involved in inflammatory processes and its inhibition can reduce inflammation ${ }^{(25)}$. This increase in MMP-9 may relate to the high neutrophil infiltration observed by tissue MPO activity as well as by high tissue damage visualized in histological analysis since these enzymes are involved in the degradation of ECM. 


\section{CONCLUSIONS}

Our results demonstrate that there is a correlation between the DAI and the degree of pathological alterations in the colon of the animals in the induced by DSS group, and these changes can be caused principally by increased expression/activity mainly on the MMP-9 and myeloperoxidase produced by inflammatory cells. Being these enzymes a possible therapeutic target for the reduction of tissue injury in treating IBD.

Oliveira LG, Cunha AL, Duarte AC, Castañon MCMN, Chebli JMF, Aguiar JAK. Correlação positiva entre índice de atividade de doença e metaloproteinase de matriz em modelo de colite em ratos. Arq Gastroenterol. 2014,51(2):107-12.

RESUMO - Contexto - Doenças inflamatórias intestinais, entre elas colite ulcerativa e doença de Crohn, compreendem um amplo espectro de doenças que apresentam em comum inflamação crônica do trato gastrointestinal, alterações histológicas e um aumento de atividade de determinadas enzimas, tais como, metaloproteinases. Objetivo - Avaliar possível correlação do índice de atividade de doença em modelo de colite ulcerativa induzida por dextran sulfato de sódio com o grau de severidade de danos na mucosa colônica e aumento de atividade de metaloproteinases. Métodos - Colite foi induzida por administração oral de dextran sulfato de sódio $5 \%$ durante sete dias no grupo $(\mathrm{n}=10)$, enquanto que o grupo controle $(\mathrm{n}=16)$ recebeu água. Efeitos foram analisados diariamente pelo índice de atividade de doença. No sétimo dia, os animais foram sacrificados e as medições hematológicas, alterações histológicas (hematoxilina e eosina e coloração de azul Alcian), mieloperoxidase e atividades de metaloproteinases (MMP-2 e MMP-9) foram determinados. Resultados - Grupo dextran sulfato de sódio mostrou elevação no índice de atividade de doença e redução dos parâmetros hematológicos. A indução da colite causa lesão no tecido, com perda de mucina e aumento da mieloperoxidase $(P<0,001)$ e as atividades MMP-9 (45 vezes) em comparação com o grupo de controle. Conclusão - Neste estudo, observamos uma correlação do índice de atividade de doença com o grau de alterações histopatológicas após indução da colite por dextran sulfato de sódio, podendo associar este resultado ao aumento principalmente da atividade de MMP-9 e de mieloperoxidase.

DESCRITORES - Colite. Doença de Crohn. Metaloproteinase.

\section{REFERENCES}

1. Baugh MD, Perry MJ, Hollander AP, Davies DR, Cross SS, Lobo AJ, et al. Matrix metalloproteinase levels are elevated in inflammatory bowel disease. Gastroenterology. 1999;117:814-22.

2. Bradley PP, Priebat DA, Christensen RD, Rothstein G. Measurement of cutaneous inflammation: estimation of neutrophil content with an enzyme marker. J Invest Dermatol. 1982;78:206-9

3. Burrage PS, Mix KS, Brinckerhoff CE. Matrix metalloproteinases: role in arthritis. Front Biosci. 2006;11:529-43.

4. Byrne FR, Viney JL. Mouse models of inflammatory bowel disease. Curr Opin Drug Discov Devel. 2006;9:207-17.

5. Colli MV, Amaro TA, Pinto ALT, Gaburri PD, Chebli JMF. Toxicidade da azatioprina na doença de Crohn: incidência, abordagem e evolução. Rev Ass Med Bras. 2008;54:415-21

6. Cooper HS, Murthy SN, Shah RS, Sedergran DJ. Clinicopathologic study of dextran sulfate sodium experimental murine colitis. Lab Invest. 1993;69:238-49.

7. Danese S, Fiocchi C. Ulcerative colitis. N Engl J Med. 2011;365:1713-25.

8. Fietz S, Bondzio A, Moschos A, Hertsch B, Einspanier R. Measurement of equine myeloperoxidase (MPO) activity in synovial fluid by a modified MPO assay and evaluation of joint diseases - an initial case study. Res Vet Sci. 2008;84:347-53.

9. Garg P, Vijay-Kumar M, Wang L, Gewirtz AT, Merlin D, Sitaraman SV. Matrix metalloproteinase-9-mediated tissue injury overrides the protective effect of matrix metalloproteinase-2 during colitis. Am J Physiol Gastrointest Liver Physiol. 2009;296:G175-84

10. Gaudio E, Taddei G, Vetuschi A, Sferra R, Frieri G, Ricciardi G, Caprilli R Dextran sulfate sodium (DSS) colitis in rats: clinical, structural, and ultrastructural aspects. Dig Dis Sci. 1999;44:1458-75.

11. Jurjus AR, Khoury NN, Reimund JM. Animal models of inflammatory bowel disease. J Pharmacol Toxicol Methods. 2004;50:81-92.

12. Kullmann F, Messmann H, Alt M, Gross V, Bocker T, Scholmerich J, Ruschoff J. Clinical and histopathological features of dextran sulfate sodium induced acute and chronic colitis associated with dysplasia in rats. Int J Colorectal Dis. $2001 ; 16: 238-46$

13. Lee B, Lee JH, Lee HS, Bae EA, Huh CS, Ahn YT, Kim DH. Glycosaminoglycan degradation-inhibitory lactic acid bacteria ameliorate 2,4,6-trinitrobenzenesulfonic acid-induced colitis in mice. J Microbiol Biotechnol. 2009;19:616-21.

14. Lee HS, Han SY, Ryu KY, Kim DH. The degradation of glycosaminoglycans by intestinal microflora deteriorates colitis in mice. Inflammation. 2009;32:27-36.

15. Medina C, Radomski MW. Role of matrix metalloproteinases in intestinal inflammation. J Pharmacol Exp Ther. 2006;318:933-8.

16. Medina C, Videla S, Radomski A, Radomski MW, Antolin M, Guarner F, et al Increased activity and expression of matrix metalloproteinase-9 in a rat model of distal colitis. Am J Physiol Gastrointest Liver Physiol. 2003;284:G116-22.
17. Melgar S, Karlsson A, Michaelsson E. Acute colitis induced by dextran sulfate sodium progresses to chronicity in $\mathrm{C} 57 \mathrm{BL} / 6$ but not in $\mathrm{BALB} / \mathrm{c}$ mice: correlation between symptoms and inflammation. Am J Physiol Gastrointest Liver Physiol. 2005;288:G1328-38.

18. Melgar S, Karlsson L, Rehnstrom E, Karlsson A, Utkovic H, Jansson L, Michaelsson E. Validation of murine dextran sulfate sodium-induced colitis using four therapeutic agents for human inflammatory bowel disease. Int Immunopharmacol. 2008;8:836-44

19. Miura RO, Yamagata S, Miura Y, Harada T, Yamagata T. Analysis of glycosaminoglycan-degrading enzymes by substrate gel electrophoresis (zymography). Anal Biochem. 1995;225:333-40.

20. Naito Y, Yoshikawa T. Role of matrix metalloproteinases in inflammatory bowel disease. Mol Aspects Med. 2005;26:379-90.

21. Okayasu I, Hatakeyama S, Yamada M, Ohkusa T, Inagaki Y, Nakaya R. A nove method in the induction of reliable experimental acute and chronic ulcerative colitis in mice. Gastroenterology. 1990;98:694-702.

22. Perse M, Cerar A. Dextran sodium sulphate colitis mouse model: traps and tricks. J Biomed Biotechnol. 2012;2012:718617.

23. Prokopowicz Z, Marcinkiewicz J, Katz DR, Chain BM. Neutrophil myeloperoxidase: soldier and statesman. Arch Immunol Ther Exp (Warsz). 2012;60:43-54.

24. Ravi A, Garg P, Sitaraman SV. Matrix metalloproteinases in inflammatory bowel disease: boon or a bane? Inflamm Bowel Dis. 2007;13:97-107.

25. Santana A, Medina C, Paz-Cabrera MC, Diaz-Gonzalez F, Farre E, Salas A, et al. Attenuation of dextran sodium sulphate induced colitis in matrix metalloproteinase-9 deficient mice. World J Gastroenterol. 2006;12:6464-72.

26. Sartor RB. Mechanisms of disease: pathogenesis of Crohn's disease and ulcerative colitis. Nat Clin Pract Gastroenterol Hepatol. 2006;3:390-407.

27. Shapiro SD, Kelley D, Kobayashi D. Measurement of metalloproteinases. Methods Mol Med. 2001;56:383-90.

28. Siasos G, Tousoulis D, Kioufis S, Oikonomou E, Siasou Z, Limperi M, et al Inflammatory mechanisms in atherosclerosis: the impact of matrix metalloproteinases. Curr Top Med Chem. 2012;12:1132-48.

29. Solomon L, Mansor S, Mallon P, Donnelly E, Hoper M, Loughrey M, Kirk S, Gardiner K. The dextran sulphate sodium (DSS) model of colitis: an overview. Comparative Clinical Pathology. 2010;19:235-9.

30. Xavier RJ, Podolsky DK. Unravelling the pathogenesis of inflammatory bowel disease. Nature. 2007;448:427-34

31. Yan Y, Kolachala V, Dalmasso G, Nguyen H, Laroui H, Sitaraman SV, Merlin D. Temporal and Spatial Analysis of Clinical and Molecular Parameters in Dextran Sodium Sulfate Induced Colitis. PLoS One. 2009;4:e6073.

Received 18/9/2013 Accepted 10/12/2013 